\title{
Teachers' Perception on the Inclusion of Students with Disabilities in the Regular Education Classroom in Ecuador
}

\author{
Ricardo Moreno-Rodríguez ${ }^{1}$, José Luis Lopez ${ }^{1}$, José David Carnicero ${ }^{1}$, Inmaculada Garrote ${ }^{1}$, Sergio Sánchez ${ }^{2}$ \\ ${ }^{1}$ Unit of Attention for People with Disabilities and Special Educational Needs, Rey Juan Carlos University, Madrid, \\ Spain \\ ${ }^{2}$ Faculty of Education, Burgos University, Burgos, Spain \\ Correspondence: Ricardo Moreno-Rodríguez, Unit of Attention for People with Disabilities and Special Educational \\ Needs, Rey Juan Carlos University, 28933 Móstoles, Madrid, Spain.
}

\author{
Received: July 5, $2017 \quad$ Accepted: July 26, $2017 \quad$ Online Published: August 2, 2017 \\ doi:10.11114/jets.v5i9.2573 URL: https://doi.org/10.11114/jets.v5i9.2573
}

\begin{abstract}
Nowadays, contradictory viewpoints are showed when defining disability. On the one hand, there are theoretical frameworks focused on the personal limitations, while, on the other hand, each time it is more extended those ones which highlight the restrictions on the social fabric. It becomes essential to integrate both frameworks considering disability as a social phenomenon besides the collective responsibility that demands further action by society as a whole.

Currently, Ecuador is suffering an economic recession due to the drop in the price of oil and the appreciation of the dollar, together with the catastrophic effects of the earthquake recorded in 2016. Before 2014, Ecuador was experiencing economic growth resulting in major investment in social areas such as education, thus promoting educational and labour market inclusion of people with disabilities.

This study shows the perspective of teachers in Ecuador towards students with disabilities before the development of a program of postgraduate studies for specializing them to cater for the special educational needs. Moreover, the aim is to assess abilities and barriers that teachers have to face up with regard to inclusion of disability in the regular classroom. The majority of teachers in Ecuador are unanimous in stating that academic career training on the issue of education inclusion and accessibility will entail a maximum support carrying out their teaching assignments as well as materials adapted to suit the students' needs. Furthermore, a wide range of teachers were aware of the case of students with disabilities in the classroom. Besides, among the main problems, architectural barriers and the lack of inclusion were the most important for the participants.
\end{abstract}

Taking all of this into consideration, it is perceived that teachers from Ecuador are not fully prepared for having students with disabilities. That is why a deeper training in special educational needs should be necessary.

Keywords: educational inclusion, Ecuador, disability, training, learning support, special educational needs

\section{Introduction}

Throughout history, the concept of disability has been a very controversial topic. On one side, there is a classical vision that is mainly focused on the limitations on the performance of activities by people with disabilities (Schalock, 1999). On the contrary, there is a tendency which highlights the restrictions on the social fabric principally emerged from prejudices, architectural barriers and even the self-perception and low self-esteem of people with disabilities themselves (Sánchez, Pedreño \& Henarejos, 2016).

Closely related to this and as indicated by Moreno-Rodríguez \& López-Bastías (2016), the conception of this group ideology and their stereotypes has definitely evolved over time and has been always linked to the concept of health and disease through the lens of the mainstream school of thought. From demonization to standardization, from exclusion to inclusion.

On account of this dichotomy, many authors express the need to reach agreement in defining disability as a construct (Jette, 2009). 
The conceptual framework carried out by Nagi (1991) is one of the most widespread; Whiteneck (2006) also suggested an example that would be useful to understand the theoretical framework in a very simple way: A person with arthritis (pathology) has joint problems (loss of anatomical functions), having as a result lack of ability to finger-tap (functional limitation), and furthermore causing the inability to occupy a job as a typist (disability). This theoretical framework focuses on the limitations of the person himself/herself, but it is important to consider a reconciliation between the medical model and the social model; so, disability needs a collective responsibility that demands further action by society as a whole. As a whole, and into a deeper non-reductionist view, disability must be defined as a social reality from a holistic perspective, since it is unique to each individual.

In other words, the nature of health condition is not the only factor that influences the individual situation of each person, it is also a complex combination of factors, not only physical or emotional, but also social besides the social status of the observer (Venegas \& Gil, 2007). The factors mentioned above are just some of the many possible scenarios, forming a range of possibilities practically infinite, in which those factors affect others in both ways, directly and indirectly.

The International Classification of Functioning, Disability and Health (ICF) defines disability as a generic term that encompasses impairments, limitations of activity and restrictions on participation. Disability is understood as the interaction between people suffering from illness and their personal and environmental factors. The accent should not be placed on the individual itself, but on the quality with which he can perform his activities of daily life in his daily life. Therefore, it is conceived as a relative and dynamic fact, related to the participation of a person at a given time and within a specific space (WHO, 2001).

On the one hand, we talk about the interaction between the person and the environment. This interaction allows the individual to make changes in the medium (which happens to be understood as a system). These changes will revert to this and other people affecting the quality of life in three different but interrelated levels, which cannot be understood separately: biological, psychological and social. In this way, the ICF conceives disability from a biopsychosocial approach, in which the functioning is understood from a complex relationship between the person with their conditions and the environment in which they live (Quejereta, 2009).

As highlighted in the World Disability Report published by the World Health Organization (WHO) in 2011, environmental factors describe the world in which people with different levels of functioning must live and act, furthermore, these factors can act as facilitators or as barriers (WHO, 2011).

Some of the barriers that impede the education of students with disabilities stem from the systemic level due to divided ministerial responsibility, lack of legislation, policies, goals and plans, and sometimes shortages of resources (Sánchez and Díez, 2016). In addition, there are school-based problems, such as curricula and pedagogy (Díez and Sánchez, 2013), insufficient training and support for teachers, not to mention both physical and attitudinal barriers, which occasionally cause acts of violence, intimidation and abuse (Recio, Galindo, Cendra, Alemany, Villaró, and Martorell, 2013). Unfortunately, there are factors that make it difficult to detect such acts of violence, intimidation and abuses, such as the lack of adapted tools, the usual communication model used by authorities (police, educators, health workers, etc.). Disability, and the credibility of the testimonies of people with Intellectual Disabilities, which is usually lower than that of persons without Intellectual Disability (Henry, Ridley, Perry and Crane, 2011; Peled, Iarocci and Connolly, 2004).

It is important to emphasize that in most current definitions, environmental, interpersonal and intrapersonal factors are especially important to understand disability and the problems that orbit around it. WHO, in the report mentioned in the previous paragraph, includes some recommendations that are based on the principle of integration and the elimination of barriers:

1. To provide access to all systems, policies and general services.

2. To invest in specific programs and services for people with disabilities.

3. To adopt a national strategy and action plan with regard to disability.

4. To involve people with disabilities.

5. To improve the skills of human resources.

6. To provide sufficient funding as well as economic affordability.

7. To increase public awareness besides understanding the concept of disability.

8. To improve data collection on aspects of disabilities.

9. To reinforce and support research projects about disability. 
In the academic field, there are no conclusive data, but some tendencies of response can be perceived. Different studies in the scientific literature (Sala \& Rosell, 2007, Suriá 2012, Díez and Sánchez, 2015) have described the perceptions of integration of students with disabilities. Among others, the main conclusions that can be made from the review are the following: University students perceive more unfavorable attitudes on the part of the teaching staff.

- Secondary students perceive less acceptance from their peers.

- Students with motor and intellectual disabilities think that their disability causes discomfort to other classmates.

Taking as a reference the data published in October 2016 by the National Council for Equality of Disabilities (CONADIS, 2008) in Ecuador, there are currently 415,500 people with disabilities in Ecuador. This represents $2.5 \%$ of Ecuador's total population (approximately 16,486,500 inhabitants)

Of the total number of people with disabilities, most have physical disabilities (47\%), followed by intellectual (22\%) and hearing (12\%). According the degree of severity of the disability, $17 \%$ are classified as "Light", $27 \%$ as "Moderate", $35 \%$ as "Severe" and $19 \%$ as "Very serious". There is a degree of correspondence between the degree of severity and the degree of disability:

- "Light" corresponds to the range of 30\% - 39\%.

- "Moderate "corresponds to the range of $40 \%-49 \%$.

- "Severe" corresponds to the range of 50\% - 74\%.

- "Very serious" corresponds to the range of $75 \%-100 \%$.

There are 73.005 persons with a level of disability between $30 \%$ and $39 \% .114 .555$ are between $40 \%$ and $49 \%, 146.528$ between $50 \%$ and $74 \%$ and, finally, 81.412 are in the range which goes from $75 \%$ to $100 \%$. As stated, more than the half of the population has big levels of disability (among 50\% and 100\%). This means that almost 227940 people suffer from important limitations to face their daily life activities (including education). This also means that it is easier to find people with high levels of disabilities rather than those with "small" limitations.

\section{Persons with disabilities registered by percentage of disability}

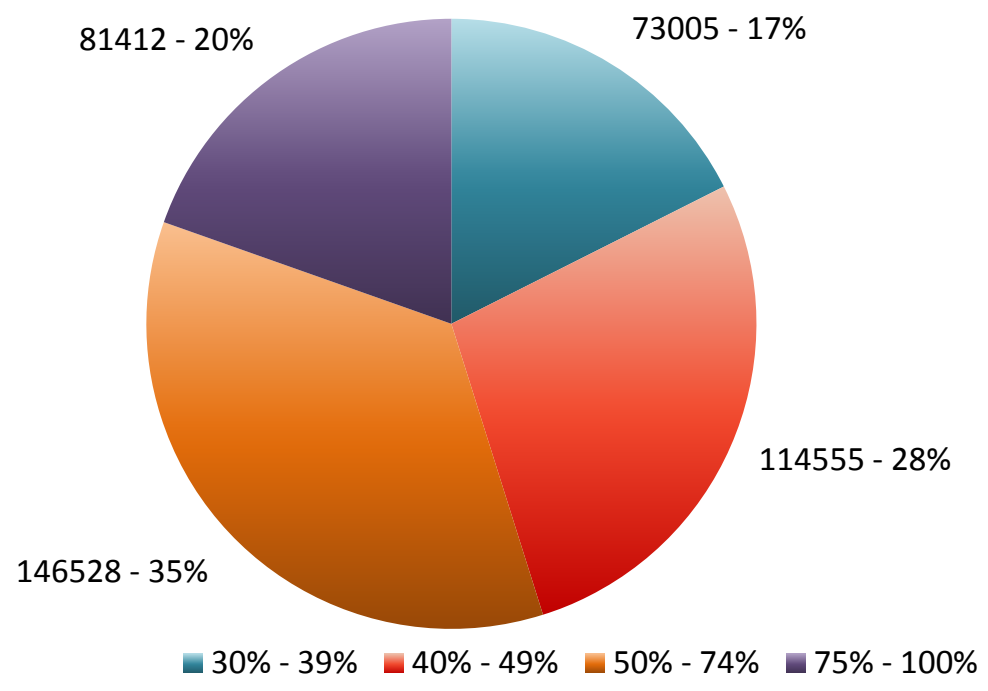

Figure 1. Persons with disabilities registered by percentage of disability. CONADIS

Prevalence of disability in men is slightly superior, but not in a significant way, compared to women: $56 \%$ of the population with disability against a $44 \%$.

Estimates indicate that there are approximately 248,000 people with disabilities, aged between 4 and 19 years. According to data released by the CERMI (Samaniego, P. y Porras, R., 2009). of the population with disabilities between 4 and 19 years attending public institutions, the vast majority (89.98\%) were in special education. They also added that the number of students with intellectual disabilities is much higher than other students with other types of disabilities. 
Currently, it is difficult for the form of accuracy of the number of people with disabilities to have access to education, as there are only state reports of this. It is estimated that only $1.8 \%$ go to higher education (Rodríguez, 2004), which is approximately 7500 people.

On the other hand, in the article 47 of the Constitution of the Republic of Ecuador (Asamblea Constituyente de Ecuador, 2008), it is recognized the rights of persons with disabilities to an education that develops their potentialities and skills for their integration and participation, under equal conditions. In addition, it shows that education will be guaranteed within regular education, the creation of specific educational centers and programs (Art. 47.8), free psychological care for the disabled and their families, especially in cases of Intellectual disability (Article 47.9), removal of architectural barriers (Art. 47.10) and the facilitation in the access to mechanisms and alternative forms of communication (Art. 47.11). Besides, through art. 347 it is established a public and autonomous evaluation institution which promotes the quality of education, emphasizing in the early detection of special requirements in schools. Also, it introduces important changes in both, initial teacher training and in sustained training processes (Article 347.2), which seeks to ensure the inclusion of students with disabilities in the regular system (Asís, 2013)

According to data presented by the World Bank, (2016), during the financial years between 2006 and 2014, average GDP grew by $4.3 \%$ due to high oil prices and significant flows of external financing.

Based on this growth, greater social spending was allowed, especially notable in areas such as education and transportation. According to national data, poverty decreased from $37.6 \%$ to $22.5 \%$ in that period.

However, in the last two years, there has been an economic contraction due to the fall in the price of oil and the appreciation of the US dollar, a currency that has been used in Ecuador since 2000. Another factor to take into account is the devastating effect of the earthquake that struck the coastal area of Ecuador, recorded in April 2016, and which has forced some 3\% of GDP to be reconstructed. Due to this, the Government of Ecuador has made it necessary to reduce public investment, which can slow down the attainment of the goals of sensitization and social and educational inclusion of people with functional diversity.

Taking all of this into consideration, it goes without saying that disability is widespread in Ecuador and, as a result of that, having students with special educational needs is really frequent. In addition, many efforts have been made by the government to improve the educational situation. However is it a proper training in this issue?

This article aims to analyze the educational capacities and accessibility to education perceived by teachers from different schools in Ecuador, in relation to students with disabilities, all a priori of the mastery of Special Needs Education (SEN).

\section{Method}

\subsection{Participants}

The sample consisted of a total of 1154 students of the Master's Degree in Attention to Special Educational Needs in Primary Education and Pre-Primary Education, all of them teachers who are working currently. The range of age of the participants varied between 22 and 48 years and about $80 \%$ of the participants were women. Participants belonged to different areas of Ecuador; in particular, the largest number of participants belonged to the provinces of El Oro (38\%) and Loja (41\%). There is a great deal of variability in terms of occupational seniority of the participants in their position as teachers. From people who took very little time ( 2 years) to people with many years of experience (34 years).

The sample has been chosen due to the close and realistic perception of the situation of people with disabilities in the classrooms of Ecuador. This perception can be provided by the participants, as teachers who know the limitations and strengths of the educational system and academic facilities. The questionnaire was done during the first moments of the mastership, so as the knowledge acquired during the master could not directly influence the responses of the participants and it could be as reliable as possible.

\subsection{Instrument}

A questionnaire containing twenty-seven questions about disability and the capacities perceived by teachers, both at professional and institutional levels, was provided to all students of the Master in Special Educational Needs in Pre-Primary and Primary Education. This questionnaire was made Ad Hoc by the teaching team of the master degree. The instrument was specifically designed to obtain a first approximation to the educational situation in Ecuador, regarding the inclusion of persons with disabilities as it was perceived by the participants, who, apart from being students of the master degree, are teachers at different schools, located in different areas of Ecuador. Items were separated into different categories:

- Awareness of disability at special educational needs at the educational center.

- Main limitations (at the educational center). 
- Main limitations (at the classroom).

- Authorities' support.

- Main resources to cope with special educational needs.

- Current training offered to deal with special educational needs.

- Training which would be necessary to deal with special educational needs.

- Perception of the level of inclusion at the educational center.

Questions were elaborated on the basis of the required information. However the issues which required a greater degree of detail were based on open questions, leading to deep answers and a greater contribution of information. Similarly, for issues which required simple answers, multiple-choice questions were offered, although there was occasionally the option of broadening the response with the answer "Other".

\subsection{Procedure}

The data presented in this article were obtained at the beginning of the master degree. What is more, the survey was facilitated via on-line, during the beginning of the first subject of the training, taking into account the motivation of the participants to answer without being influenced by the knowledge provided by the master. In this way, the acquired data corresponds to a reality perceived by the participant, who is not influenced by the knowledge and tools that can acquire during the master.

\subsection{Analysis of Data}

The tabulation and subsequent analysis of the data was carried out using the statistical analysis software SPSS (Gil, 2017), suitable for the performance of descriptive and inferential statistics in the social sciences. More specifically, the analysis carried out was descriptive, based on the data obtained from the participants' responses.

\section{Results}

Of the total number of people surveyed, $83.5 \%$ of the teachers were aware of the case of some students with disabilities in their school. $54 \%$ of them had had students with disabilities in the classroom. In most cases, they belonged to primary educational stages, with very little prevalence in higher education. In addition, most students had psychic disabilities, followed by sensory disabilities and, finally, physical disabilities.

It should be noted that there is a relatively high number of students with Down Syndrome, although it is not possible to discern the extent to which they had a real diagnosis, and it may happen that, due to ignorance, the participants could intuit a diagnosis that does not come close to reality.

The question related to the corresponding limitations that student with disability has to deal with at school; most of the answers were directed towards the architectural barriers, just along with problems related to integration and inclusion with the rest of the students. To a lesser extent, they also show that there are problems with the access to information. At the time of identifying the main limitations for students with disabilities in the different elements of the school (library, classrooms, playground, gym, sports courts, dining room, restrooms, auditorium and corridors, among others). What is more, there is a generalized idea about the lack of architectural elements that could facilitate the access and signs that could indicate how to access to the different places. While it is true that some centers are managing to reduce the limitations on student access, there is still a long way to go until full inclusion.

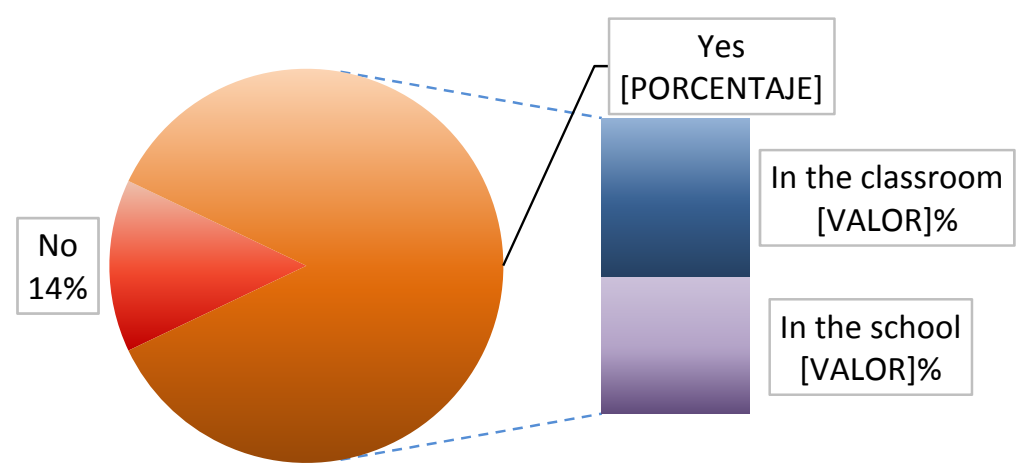

No $\square$ Yes $\square$ In the classroom $\square$ In the school

Figure 2. Knowledge of cases of disability in the school and classroom by the teachers Own elaboration 
On the other hand, regarding the limitations within the classroom, 70.4\% of teachers consider that the tables and chairs are not adapted enough to provide a full inclusion for this group. In addition, it is evident that in some cases (around $30 \%$ ), there is no a correct accessibility to the elements of the classroom (teacher's table and blackboard) and to the classroom itself. To a lesser extent, reference is made to hearing and visual problems. If we focus on the recommendations offered by Arellano and Peralta (2013), these data show us how the self-determination of students with disabilities, because of this, could be limited.

$75.5 \%$ of teachers recognize that the methodology used to impart content is not adequate for students with disabilities. When asked about which methodologies should be used according to the type of disability, the students gave very general answers, based on flexibility or on a personalized methodology for each student, but not on inclusive methodologies.

The respondents also had the opportunity to show their personal opinion regarding the quality of the training received by the teacher in terms of care for students with SEN. 37\% thought it was "Adequate", while 31\% thought it was "Good" and 24.4\% thought that it was "Poor". They also expressed their opinion about the proposed training offered to the teacher in SEN subjects, resulting in scores of 27.5\% and 28.6\% in the "Very Good" and "Good" scores, respectively. In addition, $51 \%$ believed in the need for "Ongoing training" to adequate the care for students with disabilities, while $27.7 \%$ believed that a "Training in the most common disabilities" was necessary.

They were also asked to rate from 0 to 5 (corresponding 0 to "No help" and 5 to "Maximum aid") the degree of support that would provide teachers with the following supports:

- Monitors / assistants: Most of the respondents responded with high scores, $48.9 \%$ rated the presence of monitors and / or assistants in the classroom as "maximum help".

- Signing interpreters: $56.6 \%$ of respondents felt that "Significant help" would be the presence of sign interpreters in the classroom and only $2.8 \%$ felt that they would not be "No help".

- Adapted material: A large number of respondents (69.7\%) felt that having adapted material would mean "maximum aid".

- Training: Almost all respondents agree that training is a point of great importance and help, $74.3 \%$ rated training as a key element.

\begin{tabular}{|l|cccccc|}
\hline \multicolumn{1}{|c|}{ Kind of support } & \multicolumn{6}{c|}{ Assessment of participants (percents) } \\
\cline { 2 - 7 } & 0 & 1 & $\mathbf{2}$ & $\mathbf{3}$ & $\mathbf{4}$ & $\mathbf{5}$ \\
\hline Monitors / assistants & 1.8 & 3.1 & 4.4 & 14.9 & 25.2 & 48.9 \\
Signing interpreters & 2.8 & 3.1 & 3.8 & 10.1 & 21.5 & 56.6 \\
Adapted Material & 1.6 & 1.5 & 2.3 & 7.4 & 16.1 & 69.7 \\
Training & 1.4 & 0.9 & 2.3 & 5.3 & 14.9 & 74.3 \\
\hline
\end{tabular}

Chart 1. Degree of aid estimated by participants. (Own elaboration) 


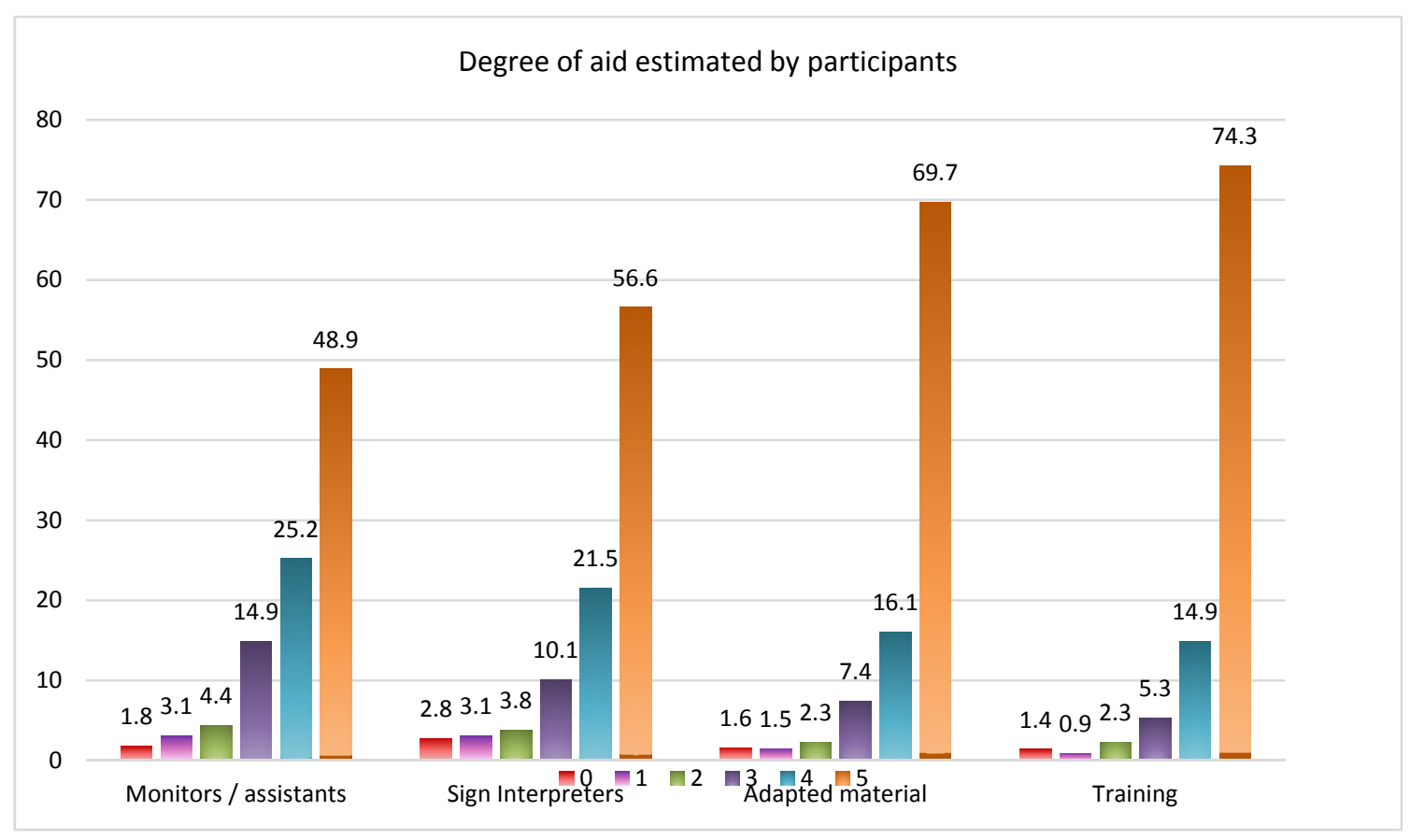

Figure 3. Degree of aid estimated by participants Own elaboration

Regarding the inclusion of students with disabilities among the rest of their classmates, $65.7 \%$ of teachers thought that students are not prepared to have a student with disabilities in their class, while $34.3 \%$ thought they would be Prepared. In addition, most seemed to agree that their school is not prepared for a correct schooling for students with motor, hearing and visual disabilities and $78.2 \%$ believed that students with disabilities generally do not reach the same level of knowledge / Competencies than the rest of their peers.

\section{Discussion}

By and large, teachers from Ecuador describe a high number of barriers, and an insufficient academic training to cope with disability and they establish the level of help received from the different kinds of supports in classroom. They perceive that schools, teachers, and students are not fully prepared to have students/mates with disabilities. Related to supports, more than $74.3 \%$ of the simple consider that academic training could be the best help to address disability in the classroom. In this situation the government of Ecuador is preparing different free distribution handbooks, and investing in academic training directed to teachers, which will have an important repercussion on kids, assuming an inclusive capability higher than the current one, where they show positive attitudes and support behaviours towards kids with disabilities.

Also it's very important to get in consideration that, in addition to architectural and formative needs there are social needs that must be attended, too (Mercado y García, 2010). According with Padilla, A. (2011), through an inclusive education we can enhance, indirectly, social and physical inclusion, based on empathic values that, sometimes, impel other people to raise their voices to evidence needs that may have most disadvantaged people.

It's foreseeable that after studying the Master's degree on Attention to Special Educational Needs in Pre-primary and Primary education teachers feels more prepared to cope and deal with a student with disability, increasing the inclusive capability and getting better the professional performance and the satisfaction of student's relatives and the satisfaction of students with disabilities.

Fortunately, since the signature of the Constitution of Republic of Ecuador (2008) some measurements are taken, focused on greater inclusion and educational improvements that will suppose, definitely, a great social and educational progress (Asís, 2013). However, the achievement of these goals as expected in the long term, due to economic recession and the difficulties associated to make changes of this magnitude in social, educational and political arenas, taking always in account the diversity in population, which gives greater complexity to this task which undoubtedly, will be performed successfully.

Since 2008, improvements in educational system have been perceived, trying to acquire more training on accessibility and inclusion for people with disabilities. In this study is evidenced the needs perceived by teachers related to more advanced training in these subjects, emphasizing the great benefits and cultural wealth that implies having people with disabilities in the educational and work environment, in addition to make ready everybody to get an independent living and a decent life. 
It's important to try to make a global vision about the current situation in Ecuador to appreciate the undoubtable will to improve the accessibility and inclusion of everybody, despite the difficulties that the country is experiencing. According to Lidón, (2013), there is still a long way to go in order to reach the full inclusion of all people, although there is undoubtedly the will and the effort necessary to achieve this goal.

One of the measures taken by the government of Ecuador has been to provide more professional training to teachers, acquiring higher education in other countries. An example of this is the Master's Degree in attention to special educational needs in pre- primary and primary education. At the time of completion of this paper, the first promotion has not been completed, so it has not been possible to compare the data provided by teachers with those that are yet to be contributed. It is expected that will be possible to compare the two moments, taking into account the effect produced by the completion of the Master's Degree.

Also it's important to have on mind that participants have been selected from the Master's degree, so we can assume that they have a certain predisposition or sensitivity towards people with disabilities. This fact supposes a difficulty to extrapolate the data obtained to all the teachers of Ecuador.

The results obtained with this study show the actions that must be taken to train teachers in attention to special needs education and inclusive education, so schools become healthy environments for all its members and, students with disabilities or special educational needs can perform their studies in an autonomous way, with the maximum level of effectiveness, and taking full advantage of their potential, showing the educational community that "disability" only implies a different set of skills and abilities that can be used to obtain more richness and more learning from diversity.

\section{References}

Arellano, A., \& Peralta, F. (2013). Autodeterminación de las personas con discapacidad intelectual como objetivo educativo y derecho básico: estado de la cuestión. Revista Española de la Discapacidad, 1(1), 97-117. https://doi.org/10.5569/2340-5104.01.01.05

Asamblea Constituyente de Ecuador (2008). Constitución de la República del Ecuador. Recuperado el 17 de Febrero de 2017 de: http://repositorio.dpe.gob.ec/bitstream/39000/638/1/NN-001-Constituci\%C3\%B3n.pdf

Asís, R. (2013). Sobre discapacidad y derecho. Madrid, España: Dykinson.

Asís, R. (2013). Sobre el modelo social de la discapacidad: Críticas y Éxito. El tiempo de los derechos, 1, 1-12.

Banco Mundial (2016). Ecuador: Panorama general. Recuperado de http://www.bancomundial.org/es/country/ecuador/overview

Consejo Nacional para la Igualdad de Discapacidades (2016). Información estadística de personas con discapacidad. Recuperado de http://www.consejodiscapacidades.gob.ec/

Díez, E., \& Sánchez, S. (2013). La educación inclusiva desde el curriculum: el diseño universal para el aprendizaje. En Rodríguez, H. (Coord.) y Torrego, L. (Coord.), TRANSFORMANDO LA ESCUELA: Educación inclusiva, equidad $y$ derecho a la diferencia (pp. 107-119). Madrid, España: Wolters Kluwer.

Díez, E., \& Sánchez, S. (2015). Diseño universal para el aprendizaje como metodología docente para atender a la diversidad en la universidad. Aula abierta, 43, 87-93. https://doi.org/10.1016/j.aula.2014.12.002

Gil, J. A. (2017). Estadística e informática (spss) en la investigación descriptiva e inferencial. (versión actualizada spss24). Editorial UNED.

Hawking, S. (2011). World Report on Disability. Geneva, Switzerland: World Health Organization.

Henry, L., Ridley, A. M., Perry, J., \& Crane, L. (2011). Perceived credibility and eyewitness testimony of children with intellectual disabilities. Journal of Intellectual Disability Research, 55(4), 385-391. https://doi.org/10.1111/j.1365-2788.2011.01383.x

Jette, A. (2009). Toward a common language of disablement. The Journals of Gerontology Series A: Biological Sciences and Medical Sciences, 64(11), 1165-1168. https://doi.org/10.1093/gerona/glp093

Lidón, L. (2013). Discapacidad y Observaciones Generales de los comités de derechos humanos de la ONU: una relación asimétrica entre la invisibilidad, el modelo médico y el modelo de derechos humanos. Revista Española de Discapacidad, 1(1), 47-72. https://doi.org/10.5569/2340-5104.01.01.03

Manzanero, A. L., Recio, M., Alemany, A., \& Pérez-Castro, P. (2013). Factores emocionales en el análisis de credibilidad de las declaraciones de víctimas con discapacidad intelectual. Anuario de Psicología Jurídica, 23(1), 21-24. https://doi.org/10.5093/aj2013a4

Mercado, E., \& García, L. M. (2010). Necesidades sociales de las personas con discapacidad en edad escolar y sus 
familias. Cuadernos de Trabajo Social, 23, 9-24.

Moreno-Rodriguez, R., \& López-Bastías, J. L. (2016). Aproximación histórica sobre los estereotipos asociados a la discapacidad: desde la prehistoria al momento actual. La ciudad accesible. Revista Científica sobre Accesibilidad Universal.

Nagi, S. (1991). Disability Concepts Revisited: Implications for Prevention. En Pope, A. \& Tarlov, A. (Ed.) Disability in America. Washington, D.C., United States of America: National Academy Press.

Organización Mundial de la Salud (OMS), (2001). Clasificación Internacional del Funcionamiento, de la discapacidad $y$ de la salud. (CIF). Ginebra: OMS

Padilla, A. (2011). Inclusión educativa de personas con discapacidad. Rev. Colomb. Psiquiat., 40(4), 670-699. https://doi.org/10.1016/S0034-7450(14)60157-8

Peled, M., Iarocci, G., \& Cannolly, D. A. (2004). Eyewitness testimony and perceived credibility of youth with mild intellectual disability. Journal of Intellectual Disability Research, 18(7), 669-703. https://doi.org/10.1111/j.1365-2788.2003.00559.x

Querejeta, M. (2009). Las herramientas del nuevo paradigma de la salud en el siglo XXI: CIE / CIF. Revista Española de Salud Pública, 83(6), 771-773. Recuperado el 07 de enero de 2017 de:

https://doi.org/10.1590/S1135-57272009000600001

Recio, M., Galindo, L., Cendra, J., Alemany, A., Villaró, G., \& Martorell, A. (2013). Abuso y Discapacidad Intelectual: orientaciones para la prevención y la actuación. Madrid: Fundación Carmen Pardo-Valcarce, FEAPS.

Rodríguez, N. (2004). Integración de las personas con discapacidad en la educación superior en Ecuador. Quito, Ecuador: UNESCO. Recuperado de http://unesdoc.unesco.org/images/0014/001404/140488s.pdf

Sala, S., \& Rosell, M. C. (2007). Estudiantes con discapacidad en las aulas universitarias: un reto para la educación superior. FIAPAS: Federación Ibérica de Asociaciones de Padres y Amigos de los Sordos, (115), 27-30.

Samaniego, P., \& Porras, R. (2009). Personas con discapacidad y acceso a servicios educativos en Latinoamérica: análisis de situación (No. 39). Madrid: CERMI.

Sánchez, A., Pedreño, M. H., \& Henarejos, M. I. F. (2016). Estrategias metodológicas para el estudio de la inserción sociolaboral de las personas con discapacidad. Revista Española de Discapacidad (REDIS), 4(1), 97-117. https://doi.org/10.5569/2340-5104.04.01.06

Sánchez, S., \& Díez, E. (2016). La implementación de contenidos sobre diseño universal en ingeniería informática y arquitectura en España. Psychology, Society \& Education, 8(1), 5.

Schalock, R. L. (1999). Hacia una nueva concepción de la discapacidad. Siglo Cero, 30(1), 5-20.

Suria, R. (2012). Se sienten integrados los estudiantes con discapacidad en su centro educativo? Análisis en función del tipo de discapacidad y etapa formativa. Profesorado. Revista de Currículum y Formación de Profesorado, 16(3), 341-356.

Venegas, J. H., \& Gil, L. M. (2007). La discapacidad, una mirada desde la teoría de sistemas y el modelo biopsicosocial. Hacia la promoción de la salud, 12(1), 51-61.

Whiteneck, G. (2006). Conceptual Models of Disability: Past, Present, and Future. En Field, M., Jette, A., \& Martin, L. (Ed.) Workshop on Disability in America: A new look (pp. 51-53). Washington, D.C., United States of America: National Academy Press.

World Health Organization (2011). World Report on Disability. Geneva, Switzerland: World Health Organization.

\section{Copyrights}

Copyright for this article is retained by the author(s), with first publication rights granted to the journal.

This is an open-access article distributed under the terms and conditions of the Creative Commons Attribution license which permits unrestricted use, distribution, and reproduction in any medium, provided the original work is properly cited. 